\title{
PENGARUH KERAGAMAN PRODUK, KUALITAS PRODUK, DAN LOKASI PENJUALAN TERHADAP KEPUASAN CUSTOMER PADA PT. RAJAWALI NUSINDO CABANG PADANG
}

\author{
Lidiana Putri, Febsri Susanti \\ Sekolah Tinggi Ilmu Ekonomi KBP \\ febsrisusanti@akbpstie.ac.id
}

\begin{abstract}
The purpose of this study was to analyze the effect of product diversity, product quality and location partially and simultaneously on customer satisfaction at PT. Rajawali Nusindo Padang Branch. The research method used is quantitative. The sampling technique used is non-probability sampling method with accidental sampling so that from the population a sample of 100 respondents was taken, the data collection method used was observation, questionnaire and literature review. Data analysis techniques used are classical assumptions, multiple linear regression and t test. Based on multiple regression analysis, get $Y=6.029+0.238 X 1+0.171 X 2+0.334 X 2+e$. From the $t$-test, it was found that the product's threat variable had a positive and significant effect on customer satisfaction at PT. Rajawali Nusindo Padang Branch. Product quality variables have a positive and significant effect on customer satisfaction at PT. Rajawali Nusindo Padang Branch. Location variables have a positive and significant effect on customer satisfaction at PT. Rajawali Nusindo Padang Branch. It is expected that the results of this study can be used as a reference for further researchers to increase the number of respondents to be used, and carried out with a longer time span, besides using variables that are more suitable to increase customer satisfaction.
\end{abstract}

Keywords: Product Diversity, Product Quality, Location and Customer Satisfaction.

\section{PENDAHULUAN}

Perkembangan dunia bisnis saat ini sangat pesat, membuat para pelaku bisnis harus saling bersaing untuk menarik para pelanggan. Para pelaku bisnis dituntut untuk inovatif/kreatif supaya bisa bertahan ditengah persaingan yang semakin ketat. Perusahaan diharapkan bisa memenuhi permintaan pelanggan.

Kepuasan pelanggan yaitu suatu hal yang sangat pentiing diperhatikan oleh pelaku usaha, supaya usaha yang didirikan dapat berjalan dengan baik. Menurut Lopiyoadi (2013:228), kebanyakan program kepuasan pelanggan bertujuan untuk meningkatkan kinerja/hasil positif pada atribut. Jadi atribut yang dianggap paling penting akan diketahui dan peningkatan kinerja dilakukan melalui atribut tersebut dengan menggunakan hubungan yang simetris, kinerja postif ditingkatkan dan kinerja yang negatif dihilangkan dimana dilakukan untuk mencapai tujuan bergantung pada sifat atau karakter atribut-atribut tersebut.

Untuk menentukan kepuasan customer tersebut dapat diketahui dari banyaknya jumlah produk yang ditawarkan oleh PT. Rajawali Nusindo, karena dengan banyaknya jumlah produk yang ditawarkan maka pelanggan akan leluasa 
memilih produk yang diinginkan. Tingkat kepuasan customer PT. Rajawali Nusindo saat sekarang sangat memprihatinkan karena masih terdapat sebagian dari jenis produk yang dimiliki oleh PT. Rajawali Nusindo yang belum dapat memenuhi permintaan pasar, sehingga customer tersebut memilih produk yang disalurkan oleh perusahaan lain dengan memiliki spesifikasi yang sama. Tingkat kepuasan customer tersebut dapat dilihat dari keragaman produk yang dimiliki oleh perusahaan.

Keragaman produk sebagai seperangkat (keanekaragaman) lini produk dan unsur yang ditawarkan oleh penjual tertentu pada para pembeli. Berdasarkan penjelasan tersebut maka dapat diketahui team marketing PT. Rajawali Nusindo tersebar di seluruh wilayah Indonesia dengan dibekali product knowledge yang sangat memadai dan siap membantu tenaga Paramedis dan Analis untuk lebih mengenal produk dari segi spesifikasi, kualitas sampai penggunaannya. Pola pembinaan dan program training yang diadakan secara berkesinambungan dan kontinyu menghasilkan tenaga-tenaga marketing yang ada handal dan profesional dibidangnya, namun dalam pemasaran produk tersebut masih terdapat kekurangan dalam memenuhi permintaan pasar, karena terdapat pada sebagian dari produk memiliki stock terbatas sehingga permintaan tersebut belum bisa terpenuhi, hal ini akan berpengaruh pada kepuasan pelanggan PT. Rajawali Nusindo.

Selain keragaman produk yang dapat menentukan kepuasan customer kualitas produk juga perlu diperhatikan oleh PT. Rajawali Nusindo karena dengan kualitas produk yang baik maka PT. Rajawali Nusindo akan dapat memberikan kepuasan kepada customernya. Namun dari kualitas produk yang dimiliki tersebut memiliki persaingan yang sangat ketat dengan perusahaan-perusahaan farmasi lainnya dengan memiliki spesifikasi yang sama serta memiliki fungsi yang sama sehingga customer tersebut memiliki pertimbangan dalam menggunakan produk tersebut, hal ini nantinya akan berpengaruh pada kepuasan pelanggan PT. Rajawali Nusindo.

Selanjutnya selain keragaman produk dan kualitas produk yang dapat menentukan kepuasan customer PT. Rajawali Nusindo, lokasi perusahaan juga perlu diperhitungkan oleh PT. Rajawali Nusindo karena dengan lokasi yang strategis dan dan mudah dilalui oleh kendaraan maka pelanggan merasa mudah untuk berkunjung ke PT. Rajawali Nusindo.

Berdasarkan penjelasan tersebut maka dapat diketahui bentuk lokasi penjualan yang dimiliki oleh PT. Rajawali Nusindo yaitu mendirikan perusahaan yang mudah dilalui oleh alat transportasi umum, namun dalam pemberian lokasi tersebut yang perlu diperhatikan kembali yaitu lokasi perkir yang disediakan karena lokasi parkir masih terbilang sempit sehingga hanya bisa menampung beberapa kendaraan beroda empat saja, hal ini nantinya akan bisa menimbulkan dampak yang kurang baik pada kepuasan customernya.

Supaya pelanggan dapat mengunjungi PT. Rajawali Nusindo dengan mudah yaitu mendirikan tempat yang dilalui oleh alat transportasi umum supaya pelanggan kesulitan untuk mengunjungi lokasi tersebut, namun dalam pemberian lokasi tersebut yang perlu diperhatikan kembali yaitu lokasi perkir yang disediakan karena lokasi perkir yang telah ada masih terbilang sempit sehingga lokasi perkir tersebut hanya menampung beberapa kendaraan beroda empat saja, 
dengan terjadinya permasalah tersebut maka pelanggan kurang puas dengan lokasi yang disediakan oleh PT. Rajawali Nusindo terutama pada lokasi parkir.

Berdasarkan uraian di atas, penulis tertarik untuk melakukan suatu penelitian dengan mengambil judul: Pengaruh Keragaman Produk, Kualitas Produk, Dan Lokasi Penjualan Terhadap Kepuasan Customer Pada Pt. Rajawali Nusindo Cab. Padang

Rumusan Masalah

1. Bagaimana pengaruh keragaman produk terhadap kepuasan customer pada PT. RajawaliNusindo Cabang Padang?

2. Bagaimana pengaruh kualitas produk terhadap kepuasan customer pada PT. Rajawali Nusindo Cabang Padang?

3. Bagaimana pengaruh lokasi penjualan terhadap kepuasan customer pada PT. Rajawali Nusindo Cabang Padang?

\section{TINJAUAN PUSTAKA}

\section{Kepuasan Customer}

Menurut Tjiptono (2014:352), kepuasan customer sudah menjadi semacam mantra ajaib yang dijumpai dihampir semua buku teks organisasi bisnis dan non bisnis, kata kepuasan pelanggan/customer seringkali dijumpai dalam memenuhi kebutuhannya. Menurut Oliver dalam Tjiptono (2012:311), indikator kepuasan customer dapat digunakan adalah perasaan yang timbul setelah mengevaluasi pengalaman pemakaian produk, respon customer, evaluasi purnabeli, ukuran kinerja produk, tingkat perasaan.

\section{Keragaman Produk}

Menurut Kotler dan Keller (2015:15) sistem produk yaitu kelompok barang yang berbeda tetapi berhubungan dan berfungsi dengan cara yang komplektibel. Bauran produk disebut (product mix) disebut jugapilihan produk (produk assortment) yaitu kumpulan semua produk dan barang yang ditawarkan untuk dijual oleh penjual tertentu. Menurut Kotler dan Keller (2015:16) indikator keragaman produk yaitu lebar bauran produk, panjang bauran produk, kedalaman bauran produk, dan konsistensi dari bauran produk.

\section{Kualitas Produk}

Menurut Kotler dan Amstrong (2008:205) mengatakan bahwa kualitas kinerja kemampuan produk untuk melakukan fungsinya. Artikan bahwa kualitas produk yaitu sejauh mana suatu produk dapat melaksanakan fungsingya dan memenuhi spesifikasi-spesifikasinya. Menurut Kotler dan Amstrong (2008:272), indikator kualitas produk pada penelitian ini yaitu kinerja (performance), daya tahan, keandalan, fitur, keindahan.

\section{Lokasi Penjualan}

Menurut Huriyati (2015:56), keputusan mengenai lokasi pelayanan yang akan digunakan melibatkan pertimbangan bagaimana menyerahkan jasa kepada customer dan dimana ituakan berlangsung. Tempat juga penting sebagai lingkungan dimana dan bagaimana jasa akan diserahkan, sebagai bagian dari nilai dan manfaat dari jasa. Menurut Huriyati (2015:57), indikator dalam lokasi yaitu akses, visibilitas, lalu lintas, tempat parkir yang luas dan aman, ekspansi, tersedia 
tempat yang cukup untuk memperluas usaha dikemudian hari,lingkungan, persaingan dan peraturan pemerintah.

\section{METODE PENELITIAN}

Dalam penelitian ini menggunakan jenis penelitian kuantitatif. Menurut Sugiyono (2012:207), jenis kuantitatif yaitu metode yang digunakan untuk menggambarkan atau menganalisis suatu hasil penelitian tetapi tidak digunakan untuk membuat kesiimpulan yang lebih luas.

Populasi dalam penelitian yaitu terdiri dari 226 outlet atau apotik yang menjadi pelanggan PT. Rajawali Nusindo Cabang. Teknik pengambilan sampelyang di gunakan dalam penelitian ini yaitu melalui non probability sampling. Berdasarkan teknik ini, tdak semua individu mendapat peluang yang sama untuk diambil sebagai sampel. Sedangkan metodenyamelalui accidental sampling yaitu mereka yang dijumpai peneliti ditempat penelitian. Berdasarkan perhitungan rumus Slovin di atas, maka jumllah sampel dalam penelitian ini sebesar 100 outlet atau apotik yang menjadi pelanggan PT. Rajawali Nusindo Cabang.

Teknik analisa data yang digunakan dalam penelitian ini adalah uji asumsi klasiik juga tidak perlu dilakukan untuk analisis regresi linear yang bertujuan untuk menghitung nilai pada variabel tertentu.

Menurut Priyatno (2010:71), normalitas digunakan untuk mengetahui apakah populasi data berdistribusi normal atau tidak. Uji ini biasanya digunakan untuk mengukur data berskala ordinal, interval atau pun rasio. Dalam pembahasan ini digunakan uji liliefors dengan meliihat nilai pada Kolmogorov-Smimov. Data dinyatakan berdistribusi normal jika signifikansi lebih besar dari 0,05. Uji normalitas ini dapat menggunakan program SPSS Versi 20.0.

Menurut Priyatno (2010:83), heteroskesdatisitas yaitu keadaan dimana terjadi ketidaksamaan varian dari residual untuk semua pengamatan pada model regresi. Uji heteroskesdatisitas dapat menggunakan uji Glejser dengan nilai signifikan $<0,05$ maka terjadi masalahheteroskesdatisitas.

Menurut Priyatno (2010:81), multikolonieritas yaitu keadaan dimana terjadi hubungan linear yang sempurna atau mendekati sempurna antar variabel bebas dalam model regresi. Selanjutnya menurut Santoso yang dikutip Prayitno (2010:81), pada umumnya jika inflation factor (VIF) lebih dari 5, maka variabel tersebut mempunyaipersoalan multikolonieritas dengan variabel bebas lainnya.

Menurut Priyatno (2010:61), analisis regresi linear berganda yaitu hubungan secara linear antara dua variabel bebas dan variabel terikat. Analisis iniuntuk memperdiksikan nilai dari variabel terikat apabila variaebl bebas mengalami kenaiikan atau penurunan dan untuk mengetahui arah hubungan antara variabel bebas dan variabel teriikat apakah masing-masing variabel berhubungan positif atau negatif.

Menurut Pardede dan Manurung (2014:28), uji F dapat diigunakan untuk menguji pengaruh secara simultan variabel bebas terhadap variabel tergantungnya (Y). Jika variabel bebas memiliiki pengaruh secara simultan terhadap variabel tergantungnya $(\mathrm{Y})$, maka model persamaan regresi masuk dala kriteria cocok atau fit. 
Menurut Pardede dan Manurung (2014:29), nilai $t_{\text {hitung digunakan untuk }}$ menguji pengaruh secara parsialterhadap variabel tergantungnya. Apakah variabel tersebut memilikipengaruh yang berarti terhadap variabel tergantungnya/tidak.

Menurut Priyatno (2010:66), analisis determinasi digunakan untuk mengetahui persentase sumbangan pengaruh variabel bebas yaitu secara serentak terhadap variabel terikat $(\mathrm{Y}) . \mathrm{R}^{2}$ sama dengan 0 , maka tidak ada sedikitpun persentase sumbangan pengaruh yang diberikan variabel bebas terhadap variabel terikat, atau variansi variabel bebas yang digunakan dalam model tidak menjelaskan sedikitpun variansi variabel teriikat.

\section{ANALISIS DAN PEMBAHASAN \\ Uji Normalitas}

Menurut Priyatno (2010:71), normalitas digunakan untuk mengetahui apakah populasi data berdistribusi normal atau tidak digunakan uji liliefors dengan melihat nilai pada Kolmogorov-Smimov. Data dinyatakan berdistribusi normal jika signifikansi lebih besar dari 0,05 . Berdasarkan hasil uji normalitas pada tabel 4.15 yaitu sebagai berikut ini:

\section{Tabel 1}

Uji Normalitas

One-Sample Kolmogorov-Smirnov Test

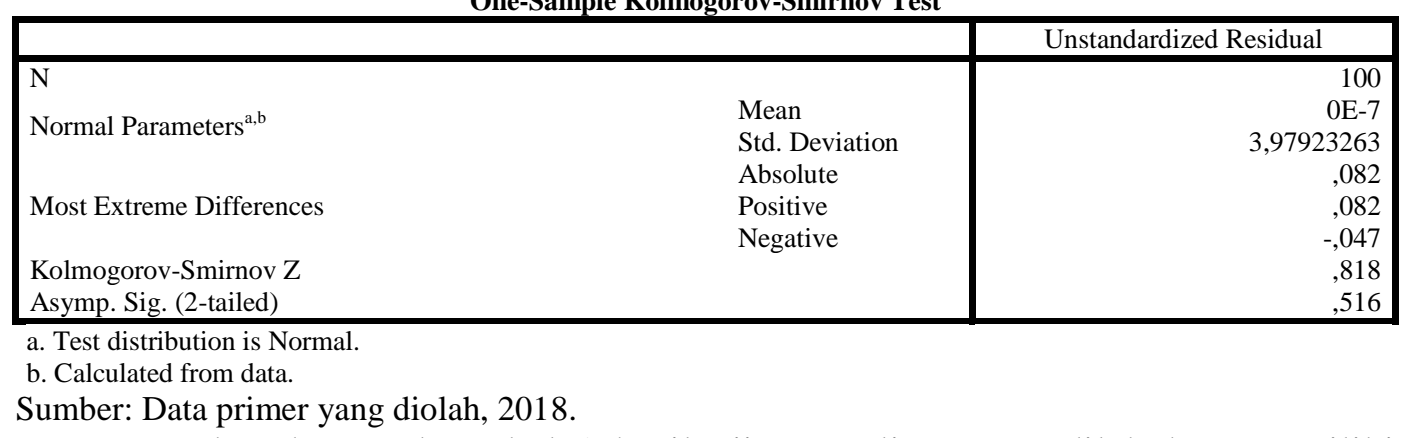

Berdasarkan pada Tabel 1 hasil uji normalitas yang dilakukan memiliki nilai Kolmogorov-Smimov sebesar 0,818 dan nilai Asymp. Sig. (2-tailed) sebesar 0,516. Jadi dapat disimpulkan bahwa data berdistribusi dengan normal karena nilai signifikan yang dihasilkan $>0,05$.

\section{Uji Heteroskedastisitas}

Menurut Priyatno (2010:83), heteroskesdatisitas yaitu keadaan dimana terjadi ketidaksamaan varian dari residual untuk semua pengamatan pada model regresi dapatmenggunakan Uji Glejser dengan nilai signifikan $<0,05$ maka terjadi masalah heteroskesdatisitas. Berdasarkan hasil penelitian uji heterokedasitisitas pada Tabel 2 yaitu sebagai berikut ini:

Tabel 2

Uji Heterokedasitisitas

\begin{tabular}{|c|l|c|c|}
\hline No. & \multicolumn{1}{|c|}{ Variabel } & Sig & Keterangan \\
\hline 1 & Keragaman poduk $\left(\mathrm{X}_{1}\right)$ & 0,076 & Tidak Terjadi Gejala Heterokesdatisitas \\
\hline 2 & Kualitas Produk $\left(\mathrm{X}_{2}\right)$ & 0,455 & Tidak Terjadi Gejala Heterokesdatisitas \\
\hline 3 & Lokasi $\left(\mathrm{X}_{3}\right)$ & 0,207 & Tidak Terjadi Gejala Heterokesdatisitas \\
\hline
\end{tabular}

Sumber: Data primer yang diolah, 2018. 
Berdasarkan pada Tabel 2 dapat diketahui bahwa nilai signifikan variabel keragaman produk, kualitas produk dan lokasi memiliki nilai signifikan $>0,05$, hal ini berarti tidak terjadi gejala heterokesdatisitas

\section{Uji Multikolonieritas}

Menurut Priyatno (2010:81), multikolonieritas yaitu keadaandimana terjadi hubungan linear yang sempurna atau mendekati sempurna antar variabel independendalam model regresi pada umumnya jika inflation factor (VIF) lebih dari 5, maka variabel tersebut mempunyai persoalan multikolonieritas dengan variabel bebas lainnya. Berdasarkan hasil penelitian uji multikolonieritas pada tabel 3 yaitu sebagai berikut ini:

Tabel 3

Uji Multikolinearitas

\begin{tabular}{|c|l|c|c|c|}
\hline \multirow{2}{*}{ No. } & \multirow{2}{*}{ Variabel } & \multicolumn{2}{|c|}{ Collinearity Statistics } & \multirow{2}{*}{ Keterangan } \\
\cline { 3 - 4 } & & Tolerance & VIF & Tidak Terjadi Multikolinieritas \\
\hline 1 & Keragaman poduk $\left(\mathrm{X}_{1}\right)$ & 0,985 & 1,016 & Tidak Terjadi Multikolinieritas \\
\hline 2 & Kualitas Produk $\left(\mathrm{X}_{2}\right)$ & 0,964 & 1,038 & Tidien \\
\hline & Lokasi $\left(\mathrm{X}_{3}\right)$ & 0,979 & 1,022 & Tidak Terjadi Multikolinieritas \\
\hline
\end{tabular}

Sumber: Data primer yang diolah, 2018.

Berdasarkan tabel 3 di atas dapat diketahui bahwa tolerance value untuk masing-masing variabel lebih besar dari 0,10 sedangkan nilai Variance Inflation Factor (VIF) untuk masing-masing variabel lebih kecil dari 10. Dengan demikian dapatdisimpulkan model yang digunakan dalam penelitian ini tidak mengandung gangguan multikolinieritas.

\section{Uji Regresi Linear Berganda}

Menurut Priyatno (2010:61), analisis regresi linear berganda yaitu hubungan secara linear antara dua variabel bebas dan variabel terikat. Berdasarkan uji regresi berganda yang dilakukandapat dilihat pada Tabel 4 di bawah ini:

Tabel. 4

Hasil Uji Regresi Linear Berganda

Coefficients $^{\mathrm{a}}$

\begin{tabular}{|c|c|c|c|c|c|}
\hline \multirow[t]{2}{*}{ Model } & \multicolumn{2}{|c|}{$\begin{array}{c}\text { Unstandardized } \\
\text { Coefficients }\end{array}$} & $\begin{array}{l}\text { Standardized } \\
\text { Coefficients }\end{array}$ & \multirow[t]{2}{*}{$\mathrm{t}$} & \multirow[t]{2}{*}{ Sig. } \\
\hline & $\mathrm{B}$ & Std. Error & Beta & & \\
\hline (Constant) & 6,029 & 5,061 & & 1,191 & ,236 \\
\hline Keragaman_Produk & ,238 & ,098 & , 197 & 2,434 & ,017 \\
\hline Kualitas_Produk & , 171 & ,083 & , 168 & 2,061 & ,042 \\
\hline Lokasi & ,334 & 049 & ,548 & 6,764 & ,000 \\
\hline
\end{tabular}

a. Dependent Variable: Kepuasan_Customer

Sumber: Data primer yang diolah, 2018.

Berdasarkan analisis data dengan menggunakan program SPSS 20 for windows, maka diperoleh hasil persamaan regresi sebagai berikut:

$\mathrm{Y}=6,029+0,238 \mathrm{X}_{1}+0,171 \mathrm{X}_{2}+0,334 \mathrm{X}_{2}+\mathrm{e}$

1) Nilai constanta yaitu $=6,029$ artinya jika tidak terjadi perubahan variabelkeragaman produk, kualitas produk dan lokasi maka nilainya yaitu 0 (nol) sehingga kepuasan customer pada PT. Rajawali Nusindo Cabang Padang tetap sebesar 6,029 satuan.

2) Nilai koefisien regresi keragaman produk yaitu $=0,238$ artinya jika variabel keragamanproduk $\left(\mathrm{X}_{1}\right)$ meningkat sebesar 1 (satuan) dengan 
asumsi variabel kualitas produk $\left(\mathrm{X}_{2}\right)$, lokasi $\left(\mathrm{X}_{3}\right)$, dan konstanta (a) yaitu 0 (nol), maka kepuasan customer pada PT. Rajawali Nusindo Cabang Padang meningkat sebesar 0,238 satuan.

3) Nilai koefisien regresi kualitas produk yaitu $=0,171$ artinya jika variabel kualitas produk $\left(\mathrm{X}_{2}\right)$ meningkat sebesar 1 (satuan) dengan asumsi variabel keragaman produk $\left(\mathrm{X}_{1}\right)$, lokasi $\left(\mathrm{X}_{3}\right)$, dan konstanta (a) yaitu 0 (nol), maka kepuasan customer pada PT. Rajawali Nusindo Cabang Padang meningkat sebesar 0,171 satuan.

4) Nilai koefisien regresi lokasi yaitu $=0,334$ artinya jika variabel lokasi $\left(\mathrm{X}_{3}\right)$ meningkat sebesar 1 (satuan) dengan asumsi variabel keragaman produk $\left(\mathrm{X}_{1}\right)$, kualitas produk $\left(\mathrm{X}_{2}\right)$, dan konstanta (a) yaitu 0 (nol), maka kepuasan customer pada PT. Rajawali Nusindo Cabang Padang meningkat sebesar 0,334 satuan.

\section{Uji Hipotesis}

\section{Uji F}

Menurut Pardede dan Manurung (2014:28), uji F dapat digunakan untuk menguji pengaruh secara simultanvariabel bebas terhadap variabel tergantungnya (Y). Jika variabel bebas memilikipengaruh secarasimultan terhadap variabel tergantungnya.Berdasarkan uji $\mathrm{F}$ yang dilakukan dapat dilihat pada Tabel 5 di bawah ini:

\section{Tabel 5}

Hasil Uji F (Simultan)

ANOVA $^{\mathrm{a}}$

\begin{tabular}{|rl|r|r|r|r|r|}
\hline Model & & Sum of Squares & \multicolumn{1}{|c|}{ df } & Mean Square & F & Sig. \\
\hline \multirow{3}{*}{1} & Regression & 974,515 & 3 & 324,838 & 19,893 &, $000^{\mathrm{b}}$ \\
& Residual & 1567,595 & 96 & 16,329 & & \\
& Total & 2542,110 & 99 & & & \\
\hline
\end{tabular}

a. Dependent Variable: Kepuasan_Customer

b. Predictors: (Constant), Lokasi, Keragaman_Produk, Kualitas_Produk

Sumber : Data primer yang diolah, 2018.

Berdasarkan hasil pengujian pada tabel di atas dapat dilihat pada nilai $\mathrm{F}_{\text {hitung }}$ sebesar 19,893 dengan nilai signifikan $<0,05$ maka Ho ditolak dan $\mathrm{H}_{3}$ diterima. Sehingga dapatdisimpulkanbahwa variabel keragaman produk $\left(\mathrm{X}_{1}\right)$, kualitas produk $\left(\mathrm{X}_{2}\right)$ dan lokasi $\left(\mathrm{X}_{2}\right)$ secara bersamaan berpengaruh signifikan terhadap kepuasan customer pada PT. Rajawali Nusindo Cabang Padang.

\section{Uji t}

Menurut Pardede dan Manurung (2014:29), nilai $t_{\text {hitung diigunakan untuk }}$ menguji pengaruh secara parsialterhadap variabel tergantungnya. Apakah variabel tersebutmemiliki pengaruh yangberarti terhadap variabel tergantungnya $(\mathrm{Y})$ atau tidak. Berdasarkan uji t yang dilakukan dapat dilihat pada Tabel 6 di bawah ini: 
Tabel 6

Hasil Uji t (Parsial)

Coefficients $^{\mathrm{a}}$

\begin{tabular}{|c|c|c|c|c|c|}
\hline \multirow[t]{2}{*}{ Model } & \multicolumn{2}{|c|}{ Unstandardized Coefficients } & \multirow{2}{*}{$\begin{array}{c}\begin{array}{c}\text { Standardized } \\
\text { Coefficients }\end{array} \\
\text { Beta }\end{array}$} & \multirow[t]{2}{*}{$\mathrm{t}$} & \multirow[t]{2}{*}{ Sig. } \\
\hline & B & Std. Error & & & \\
\hline (Constant) & 6,029 & 5,061 & & 1,191 & ,236 \\
\hline Keragaman_Produk &, 238 & ,098 & 197 & 2,434 & 017 \\
\hline Kualitas_Produk &, 171 & 083 &, 168 & 2,061 &, 042 \\
\hline Lokasi & ,334 & 049 & ,548 & 6,764 &, 000 \\
\hline
\end{tabular}

a. Dependent Variable: Kepuasan_Customer

Sumber : Data primer yang diolah, 2018.

Variabel keraaman produk $\left(\mathrm{X}_{1}\right)$ berpengaruh secara positif dan signifikan terhadapkepuasan customer pada PT. Rajawali Nusindo Cabang Padang dengan nilai $t_{\text {hitung }}$ sebesar 2,434 sedangkan nilai signifikan $<0,05$, maka Ho ditolak dan $\mathrm{H}_{1}$ diterima.

Variabel kualitas produk $\left(\mathrm{X}_{2}\right)$ berpengaruh secara positif dan signifikan terhadap kepuasancustomer pada PT. Rajawali Nusindo Cabang Padang dengan nilai $t_{\text {hitung }}$ sebesar 2,061 sedangkan nilai signifikan $<0,05$, maka Ho ditolak dan $\mathrm{H}_{2}$ diterima.

Variabel lokasi $\left(\mathrm{X}_{3}\right)$ berpengaruh secara positif dansignifikan terhadap kepuasan customer pada PT. Rajawali Nusindo Cabang Padang dengan nilai $\mathrm{t}_{\text {hitung }}$ sebesar 6,764 sedangkan nilai signifikan $<0,05$, maka Ho ditolak dan $\mathrm{H}_{3}$ diterima. Uji Koefisien Determinasi $\left(\mathbf{R}^{2}\right)$

Menurut Priyatno (2010:66), analisis determinasi digunakan untuk mengetahui persentase sumbangan pengaruh variabel bebas yaitu secara serentak terhadap variabel terikat (Y). Berdasarkan uji koefisiendeterminasi yang dilakukan maka dapat dilihat pada Tabel 7 berikut ini:

\section{Tabel 7}

Hasil Uji Koefisien Determinasi $\left(\mathbf{R}^{2}\right)$

Model Summary

\begin{tabular}{|l|r|r|r|r|r|r|r|r|r|}
\hline Model & $\mathrm{R}$ & \multirow{2}{*}{$\begin{array}{c}\mathrm{R} \\
\text { Square }\end{array}$} & $\begin{array}{c}\text { Adjusted } \\
\mathrm{R} \text { R Square }\end{array}$ & $\begin{array}{c}\text { Std. Error } \\
\text { of the } \\
\text { Estimate }\end{array}$ & $\begin{array}{c}\mathrm{R} \\
\text { Square } \\
\text { Change }\end{array}$ & $\begin{array}{c}\mathrm{F} \\
\text { Change }\end{array}$ & df1 & df2 & $\begin{array}{c}\text { Sig. F } \\
\text { Change }\end{array}$ \\
\hline 1 &, $619^{\mathrm{a}}$ &, 383 &, 364 & 4,041 &, 383 & 19,893 & 3 & 96 &, 000 \\
\hline
\end{tabular}

a. Predictors: (Constant), Lokasi, Keragaman_Produk, Kualitas_Produk

Sumber: Data primer yang diolah, 2018.

Berdasarkan Tabel 7 dapat diketahui bahwa nilai koefisien determinasi terdapat pada nilai Adjusted $R$ Square dengan sebesar 0,364. Hal ini berarti sumbanganvariabel bebas dalam menjelaskan variabel terikat yaitusebesar $36,4 \%$ sisanya $63,6 \%$ dijelaskan oleh variabel lain yang tidak dibahas dalam penelitian ini.

\section{Pembahasan Hasil Penelitian}

\section{1) Pengaruh Variabel Keragaman Produk Terhadap Kepusan Customer.}

Dari hasil analisis uji hipotesapada tingkat kepercayaan $\alpha=5 \%$ terbukti bahwa variabel keragaman produk $\left(\mathrm{X}_{1}\right)$ berpengaruh secara positif dan signifikan terhadap kepuasan customer pada PT. Rajawali Nusindo Cabang Padang dengan 
nilai $t_{\text {hitung }}$ sebesar 2,434 sedangkan nilai signifikan $<0,05$. Berdasarkan hasil penelitian tersebut dapatdisimpulkan bahwa kepuasancustomer pada PT. Rajawali Nusindo Cabang Padang disebabkan karena keragamanproduk yang dilakukan oleh perusahaan, hal ini dapat diketahui dari indikator keragaman produk seperti lebar bauran produk, panjang bauran produk, kedalaman bauran produk dan konsistensi dari bauran produk, sehingga dengan memberikan berbagai jenis produk maka dapat meningkatkan kepuasan pelanggan, karenapermintaan pelanggan tersebut dapat terpenuhi dengan baik.

Hasil penelitian inisama dengan penelitian Nainggolan, dkk (2016) menjelaskan bahwa keragaman produk mempunyai pengaruh yang signifikan terhadap kepuasan customer. Berdasarkan penelitian diketahuibahwa keragaman produk (menu) pada Stove Syndicate Cafe Semarang termasuk dalam katagori bervariasi. Hal ini membuktikanbahwa Stove Syndicate Cafe Semarang sudah dengan baik dalammenciptakan penawaran yang beragam demi pemenuhan kepuasan pelanggan serta keingginan pelanggan yang beragam dan berbeda-beda pula.

2) Pengaruh Variabel Kualitas Produk Terhadap Kepuasan Customer.

Dari hasil analisis uji hipotesa pada tingkat kepercayaan $\alpha=5 \%$ terbukti bahwa variabel kualitas produk $\left(\mathrm{X}_{2}\right)$ berpengaruh secara positifdan signifikan terhadap kepuasan customer pada PT. Rajawali Nusindo Cabang Padang dengan nilai $t_{\text {hitung }}$ sebesar 2,061 sedangkan nilaisignifikan $<0,05$. Berdasarkan hasil tersebut dapat disimpulkanbahwa kepuasan customer pada PT. Rajawali Nusindo Cabang Padang disebabkan kerena kualitas produk yang diberikan oleh perusahaan, hal ini dapat diketahui dariindikator kualitasproduk seperti kinerja (performance), daya tahan, kehandalan, fitur dan keindahan,sehingga dengan memberikan kualitas produk yang baik tersebut maka bisa memberikan kepuasan yang baik kepada pelanggan, karena kualitas produk tersebut telah sesuai yang diinginkan oleh pelanggan.

Hasil penelitian ini sama dengan penelitian Hanjaya (2016) menjelaskan bahwa kualitas produk memiliki pengaruh signifikan secara positif terhadap variabel keputusan pembelian (Y). Hal ini membuktikan bahwa hipotesis pertama dalam penelitian ini yang menyatakan bahwa variabel kualitasproduk memiliki pengaruh secara positif terhadap keputusan pembelian produk CapraLatte dapat diterima. Kesegaran produk Capra Latte harus terus dijaga dengan cara menjaga tempat penyimpanan dan tidak menyimpan produk terlalu lama agarpelanggan dapat menikmati susu kambing etawa yang segar dan merasakan manfaatnya.

\section{3) Pengaruh Variabel Lokasi Terhadap Kepuasan Customer.}

Dari hasil analisis uji hipotesa pada tingkat kepercayaan $\alpha=5 \%$ terbukti bahwa variabel lokasi $\left(\mathrm{X}_{3}\right)$ berpengaruh secara positif dan signifikan terhadap kepuasan customerpada PT. Rajawali Nusindo Cabang Padangdengan nilai thitung sebesar 6,764 sedangkan nilai signifikan $<0,05$. Berdasarkan hasil tersebut dapat disimpulkan bahwa kepuasan customer pada PT. Rajawali Nusindo Cabang Padang disebabkan kerena lokasi berdirinya PT. Rajawali Nusindo Cabang Padang, hal ini dapatdiketahui dari indikator lokasi seperti akses, visibilitas, lalu lintas (traffic), tempat parkir yang luas dan aman,ekspansi, lingkungan, persaingan dan peraturan pemerintah, dengan berbagaifasilitas lokasi yang dimiliki oleh PT. 
Rajawali Nusindo Cabang Padang maka dapat mempermudah pelanggan untukmengunjungi perusahaan tersebut, sehingga memberikan tersendiri bagi pelanggan yang telah berlanggan dengan PT. Rajawali Nusindo Cabang Padang.

Hasil penelitian ini sama dengan penelitian Nainggolan, dkk (2016) menjelaskan bahwa lokasimempunyai pengaruh yang signifikan terhadap kepuasan customer. Berdasarkan penelitian diketahui bahwa lokasi Stove Syndicate Cafe Semarang termasuk dalam katagori strategis. Hal ini membuktikan bahwa Stove Syndicate Cafe Semarangsudah dengan tepat memilih lokasi yaitu dekat dengan tempat tinggal parakomsumen yang sebagian besar yaitu kalangan mahasiswa. Hal ini membuktikanbahwa lokasi yang mudah dijangkau oleh pelanggan akan menimbulkan kepuasan pelanggan.

\section{SIMPULAN}

1. Variabel keragaman produk berpengaruh secara positif dan signifikan terhadapkepuasan customer pada PT. Rajawali Nusindo Cabang Padang dengan nilai signifikan $<0,05$.

2. Variabel kualitas produk berpengaruh secara positif dan signifikan terhadap kepuasancustomer pada PT. Rajawali Nusindo Cabang Padang dengan nilai signifikan $<0,05$.

3. Variabel lokasi berpengaruh secara positif dan signifikan terhadap kepuasan customer pada PT. Rajawali Nusindo Cabang Padang dengan nilai signifikan $<0,05$.

\section{DAFTAR PUSTAKA}

Abdullah, Thamrin dan Tantri, Francis. 2016. Manajemen Pemasaran. Cetakan kelima. Jakarta: Rajawali Pers.

Andika, A., \& Susanti, F. (2018). Pengaruh Marketing Mix Terhadap Keputusan Pembelian Parfum di Azzwars Parfum Lubeg Padang. https://doi.org/10.31227/osf.io/upgc3.

Assauri,Sofjan.2014.ManajemenPemasaran. Jakarta: PT Raja Grafindo Persada.

Aziz, N. (2019). Analisis Pengaruh Kualitas Produk, Harga, Promosi Terhadap Keputusan Pembelian Air Minum Dalam Kemasan (AMDK) Merek Aicos $\begin{array}{llll}\text { Produksi Pt. } & \text { Bumi } & \text { Sarimas }\end{array}$ https://doi.org/10.17605/OSF.IO/8XKYB

Aziz, N. (2019). Pengaruh Atribut Produk Terhadap Minat Beli Sepeda Motor Honda Dealer Amanah Lubuk Alung. https://doi.org/10.17605/OSF.IO/BNDAE

Handoko, Hani. 2012. Dasar-Dasar Manjemen Produksi dan Operasi. Edisi 1. Cetakan Tujuh Belas. Yogyakarta: BPFE. Yogyakarta Anggota IKAPI.

Heizer, Jay dan Barry Render. 2012 Manajemen Operasi (Buku 1 Edisi 10) Jakarta: Salemba Empat.

Hurriyati, Ratih. 2015. Bauran Pemasaran dan Loyalitas Konsumen, Bandung: CV. Alfabeta. 
Kismanto, Anjar, Hari. 2011. Pengaruh Harga, Lokasidan Fasilitas Terhadap Keputusan Berkunjung Wisatawan di Objek Wisata Dampo Awang Beach Rembang. Skripsi. Universitas Negeri Semarang.

Kotler, Philip dan Amstrong, Garry. 2008. Prinsip-Prinsip Pemasaran. Jakarta: Erlangga.

Kotler, Philip. and Keller, K.L. 2009. Marketing Management: $13^{\text {th }}$ Edition.New Jersey: Upper Saddle River.

Kotler, Philip dan Keller, Kevin. 2012. Marketing Manajemen. Edisi 14. Global Edision Pearson. Prentice.

Kotler, Philip dan Keller, Kevin, Lane. 2015. Manajemen Pemasaran. Edisi Tigabelas. Jilid Kedua. Jakarta: Penerbit Erlangga.

Kurniawan, Arief Rakhman. 2014. Total Marketing. Yogyakarta: Kobis.

Loredah Paulina Nainggolan, Ari Pradhanawati dan Wahyu Hidayat. 2016. Pengaruh Kualitas Pelayanan, Keragaman Produk dan Lokasi Terhadap Kepuasan Pelanggan (Studi Kasus Pada Pelanggan Stove Syndicate Cafe di Semarang). Diponegoro Journal Of Social And Political Of Science Tahun 2016.

Lupiyoadi, Rambat. 2013. Manajemen Pemasaran Jasa Berbasis Kompetensi. Edisi 3. Jakarta: Salemba Empat.

Ma’ ruf, Hendry. 2006. Pemasaran Ritel. Jakarta: PT. Gramedia Pustaka Utama.

Marlius, D. (2017). Keputusan Pembelian Berdasarkan Faktor Psikologis Dan Bauran Pemasaran Pada PT. Intercom Mobilindo Padang. Jurnal Pundi. Volume 1. No. 1. Hal. 57-66. https://doi.org/10.31575/jp.v1i1.9

Marlius, D. (2016). Pengaruh Bauran Pemasaran Jasa Terhadap Minat Nasabah Dalam Menabung Pada Bank Nagari Cabang Muaralabuh. https://doi.org/10.31227/osf.io/vdqgx

Mayliza, R. (2019). Analisis Keputusan Pembelian Ulang Axis Ditinjau Dari Bauran Pemasaran Kasus Di Kota Padang. https://doi.org/10.31219/osf.io/e7xhy

Mazin. 2016.Pengaruh Harga, Keragaman Produk, dan Mutu Pelayanan Terhadap Kepuasan Konsumen Pada Toko Bahan Bangunan UD Berkat Subur Bujuel Kota Kediri. Skripsi. Fakultas Ekonomi. Universitas Nusantara Persatuan Guru Republik Indonesia UN PGRI Kediri.

Meidisa, C., \& Susanti, F. (2019). Pengaruh Preferensi Dan Pengetahuan Produk Terhadap Minat Menabung Masyarakat Pada Bank Nagari Unit Layanan Syariah Cabang Pasar Raya Padang. https://doi.org/10.31227/osf.io/bf7cr

Mowen C. John \& Minor Michael. 2011. Perilaku Konsumen. Diterjemahkan oleh Lina Salim. Bandung: Erlangga.

Nurhasanah. 2010. Analisis Pengaruh Keragaman Produk, Kualitas Pelayanan dan Kepuasan Pelanggan Terhadap Loyalitas Pelanggan Pada PT. Hero Supermarket Tarogong Cilandak Jakarta Selatan. Skripsi. Fakultas Ekonomi dan Bisnis. Universitas Islam Negeri Syarif Hidayahtullah Jakarta.

Pardede, Ratlan, dan Manurung, Renhard. 2014. Analisis Jalur/Path Analisis Teori dan AplikasiDalam Riset Bisnis, Cetakan Pertama. Jakarta: PT. Rineka Cipta. 
Priyatno, Duwi. 2010.Pemahaman Analisis Statistik Data Dengan SPSS. Jakarta: PT. Buku Seru.

Purnama, Nursya Bani. 2006. Manajemen Kualitas: Perspektif Global. Yogyakarta: Ekonisia.

Qin, H dan Prybutok, V.R. 2010. Service Quality, Customer Satisfaction, and Behavioral Intention in Fast Food Restaurant. International Journal of Quality and Services Sciences, Vol. 1, pp 78-95.

Sangadji, Etta, Mamang, dan Sopiah. 2013. Perilaku Konsumen.Yogyakarta: Cv. Andi Offset.

Sanny Hanjaya. 2016. Pengaruh Kualitas Produk, Pengetahuandan Keragaman Menu Terhadap Keputusan Pembelian Produk Capra Latte. Fakultas Manajemen Bisnis, Universitas Ciputra, Surabaya. Performa: Jurnal Manajemen dan Start-Up Bisnis Volume 1, Nomor 2, Juni 2016.

Sarjita. 2017.Analisis Pengaruh Harga, Pelayanan, Atmosfer Kenyamanan, Keragaman Produk dan Desain Rumah Sakit Terhadap Keputusan Konsumen di Rumah Sakit Bethesda Yakkum Yogyakarta. Akademi Manajemen Administrasi YPK Yogyakarta. JBMA - Vol. IV, No. 1, Maret 2017. ISSN : 2252-5483.

Sri, Wilujeng dan Mohammad Fakhruddin Mudzakkir. 2015. Pengaruh Keragaman Produk Terhadap Kepuasan Pelanggan Pada Toko Modern Indomaret Kecamatan Sukun Kota Malang. Prodi Manajemen FEB Universitas Kanjuruhan Malang. Moderniasi Volume 11, Nomor 2, Juni 2015.

Sugiyono. 2012. Metode Penelitian Pendidikan Pendekatan Kuantitatif, Kualitatif, dan R\&D. Bandung: Alfabeta.

Sugiyono. 2014.Metode Penelitian Kuantitatif dan Kualitatif dan R\&D. Bandung: Penerbit Alfabeta.

Sunyoto, Danang. 2014. Konsep Dasar Riset Pemasaran dan Perilaku Konsumen.

Yogyakarta: PT. Buku Seru.

Swastha, Basu. 2010.Manajemen Pemasaran Modern. Yogyakarta: Liberty.

Swastha, Basu, dan Irawan. 2010. Manajemen Pemasaran Analisis Perilaku Konsumen. Yogyakarta: Liberty.

Tjiptono, Fandy. 2012. Service Manajemen Menwujudkan Pelayanan Prima. Edisi

2. Yogyakarta: CV. Andi Offset.

Tjiptono, Fandi, 2014. Pemasaran Jasa- Prinsip, Penerapan, Penelitian. Yogyakarta: CV. Andi Offset.

Tjiptono, Fandy.2015. Strategi Pemasaran. Edisi Keempat. Yogyakarta: C.V. Andi Offset.

Umar, Husein. 2008. Metode Riset Bisnis. Jakarta: PT. Gramedia. Pustaka Utama. Utami, Christina W. 2008.Manajemen Ritel. Edisi Kedua. Jakarta: Salemba Empat. 